\title{
The application of bone morphogenetic proteins in medicine, dentistry, sport and rehabilitation: A review of literature
}

\author{
Authors' Contribution: \\ A Study Design \\ B Data Collection \\ C Statistical Analysis \\ D Data Interpretation \\ E Manuscript Preparation \\ F Literature Search \\ G Funds Collection
}

\author{
Aleksandra Jaroń1 ABDEF, Elżbieta Grzywacz ${ }^{2 ~ B E F}$, Natalia Kerber-Wyka ${ }^{2}$ BEF, \\ Sara Zacharska ${ }^{\text {BEF }}$, Michał Łobacz ${ }^{3}$ BF, Grzegorz Trybek ${ }^{1}$ ABDEF \\ ${ }^{1}$ Department of Oral Surgery, Pomeranian Medical University in Szczecin, Poland \\ ${ }^{2}$ Students Scientific Club of Oral Surgery in Department of Oral Surgery, \\ Pomeranian Medical University in Szczecin, Poland \\ ${ }^{3}$ Chair and Department of Oral Surgery, Medical University of Lublin, Poland
}

\section{abstract}

Key words: BMP, bone morphogenetic proteins, oral surgery, bone regeneration, sport, medicine.

\section{article details}

Article statistics: Word count: 3,487; Tables: 0; Figures: 1; References: 90

Received: October 2020; Accepted: November 2020; Published: December 2020

Full-text PDF:

Bone tissue is a mineralized structure with a complicated metabolism and due to its mechanical functions its structure must be adapted to the bone function. The BMP protein group stimulates the formation of bone and cartilage and influences numerous non-osteogenic processes. As a result of their osteogenic effect, BMP proteins are used in numerous areas of medicine, including dentistry and orthopaedics, as well as sport and rehabilitation.

The publications used in this paper were sourced from the PubMed and the Google Scholar databases. The index entries used to search the databases included BMP, bone morphogenetic proteins, medicine, dentistry and sport.

BMP proteins have a wide range of applications, particularly in dentistry and sports medicine. The study demonstrates that autogenous material is the best for bone regeneration as a result of using resources of BMP proteins and bone-forming cells. Undeniably, the condition of the patient's body undergoing treatment with BMP is not without significance. According to the authors of the article, all applications and treatment options with the use of BMPs are yet to be known. Perhaps further development of medicine will make their discovery possible.

Copyright ๑ Gdansk University of Physical Education and Sport, Poland

Indexation: Celdes, Clarivate Analytics Emerging Sources Citation Index (ESCI), CNKI Scholar (China National Knowledge Infrastructure), CNPIEC, De Gruyter - IBR (International Bibliography of Reviews of Scholarly Literature in the Humanities and Social Sciences), De Gruyter - IBZ (International Bibliography of Periodical Literature in the Humanities and Social Sciences), DOAJ, EBSCO - Central \& Eastern European Academic Source, EBSCO - SPORTDiscus, EBSCO Discovery Service, Google Scholar, Index Copernicus, J-Gate, Naviga (Softweco, Primo Central (ExLibris), ProQuest - Family Health, ProQuest - Health \& Medical Complete, ProQuest - Illustrata: Health Sciences, ProQuest - Nursing \& Allied Health Source, Summon (Serials Solutions/ProQuest, TDOne (TDNet), Ulrich's Periodicals Directory/ulrichsweb, WorldCat (OCLC)

Funding: This research received no specific grant from any funding agency in the public, commercial, or not-for-profit sectors.

Conflict of interests: Corresponding author:

Open Access License:
Authors have declared that no competing interest exists.

Aleksandra Jaroń; Department of Oral Surgery, Pomeranian Medical University in Szczecin; al. Powstańców Wielkopolskich 72/18, 70-111 Szczecin, tel. 48 914661736; email: jaronola@gmail.com

This is an open access article distributed under the terms of the Creative Commons Attribution-Non-Commercial-NoDerivatives 4.0 International (https://creativecommons.org/licenses/by-nc-nd/4.0/), which permits use, distribution and reproduction in any medium, provided the original work is properly cited, the use is non-commercial and is otherwise in compliance with the license. 


\section{INTRODUCTION}

Bone tissue is a mineralized structure with a complicated metabolism and due to its mechanical functions its structure must be adapted to the bone function. Bone physiology includes two phases, namely modelling and reconstruction. Modelling is a process that takes place during bone development. Reconstruction is a process that takes place throughout the whole life of the body and at the first stage involves osteoclasts resorbing a mixture of substances in which the main component is collagen type I and hydroxyapatite [1]. Then the osteoblasts responsible for synthesizing a new matrix, which contains type I collagen and osteocalcin, matrix proteins (MGP), osteopontins, growth factors, such as bone morphogenetic (BMP) proteins and the transforming growth factor $\beta$ (TGF- $\beta$ ) [2], are directed into the resorbed area. In the remodelling process, the balance between functions of osteoclasts and osteoblasts is important, and in the absence of this balance, bone diseases occur [3]. The BMP protein group stimulates the formation of bone and cartilage and influences numerous non-osteogenic processes. These molecules primarily stimulate the differentiation of mesenchymal stem cells into chondroblasts and osteoblasts [4, 5].

As a result of their osteogenic effect, BMP proteins are used in numerous areas of medicine, including dentistry and orthopaedics, as well as sport and rehabilitation. In addition to bone repair, BMPs are involved in cellular and developmental processes, including muscle mass regulation muscle and bone crosstalk, neurogenesis, as well as inflammation. This family of proteins may prove useful in designing regenerative therapies in dental surgery and periodontology. In the near future, these advances are likely to be applied in periodontal surgery. They may help the approach to the regeneration of entirely lost periodontal structures [6]. They are used, among others, in the regeneration of periodontium with bone defects in the furrow [7]. BMPs also prove to be very promising in promoting wound healing of dental implants [8]. The article presents different types of BMP proteins used in the treatment of orthopaedic injuries, as well as other clinical areas [9].

The publications used in this paper were sourced from the PubMed and the Google Scholar databases. We searched for possible applications of BMP proteins in sport, medicine, and dentistry. The index entries used to search the PubMed and Google Scholar browsers included BMP, bone morphogenetic proteins, medicine, dentistry and sport.

\section{BONE MORPHOGENETIC PROTEINS (BMP) AND GROWTH FACTORS (GDF)}

Bone morphogenetic proteins, BMPs, and the transforming growth factor, TGF- $\beta$, are part of the superfamily of the transforming growth factor TGF- $\beta$. They play a key role in tissue development, homeostasis of mature tissues and pathogenesis of bone tissue diseases [4, $5]$. The TGF- $\beta$ superfamily may be divided into four subgroups with different mechanisms of bonding and receptor activation. These subgroups are TGFbs, bone morphogenetic proteins (BMP) and growth factors as well as growth differentiation factors (GDF), activin/ inhibin and a subgroup composed of factors which do not match the above three [10]. This is the largest subgroup in the TGF- $\beta$ family. The classes distinguished within its area are as follows:
- BMP2/4
- BMP 5/6/7/8
- GDF 5/6/7
- BMP 9/10
- GDF $1 / 3$
- BMP3/ GDF10
- GDF8 / GDF11
- BMP15 / GDF9 

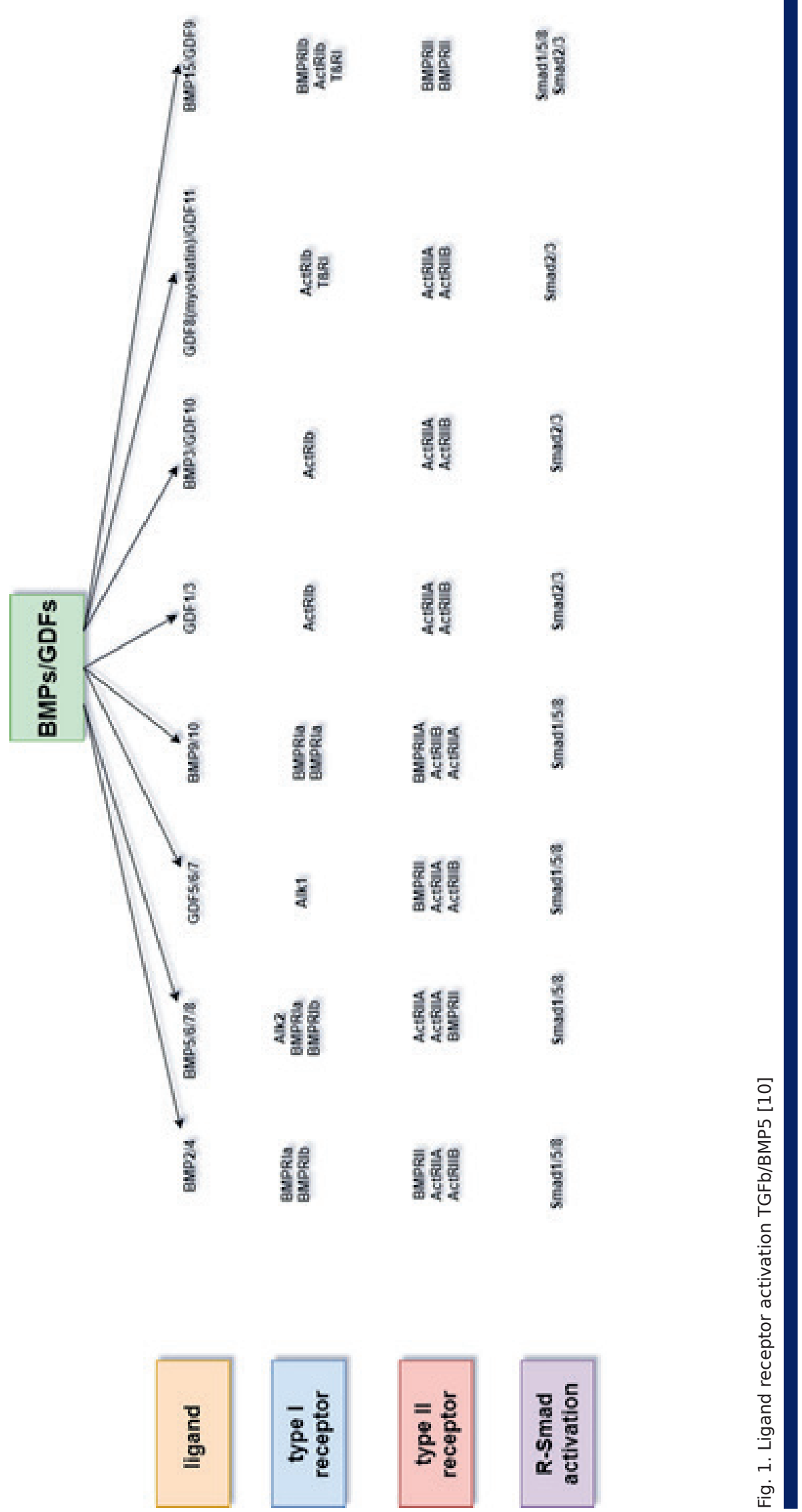


\section{BMP-2}

This protein was discovered in 1965 by Urist and then in 2007 it was approved as recombinant human rhBMP-2 in dentistry, where it is used for surgical procedures such as bone grafting and maxillary sinus surgery [11]. It is a regulator of cartilage and bone structure. It comes from the superfamily of TNF-Beta [12]. It is composed of 396 amino acids [12], of which they are signal sequences [13, 14]. It is an acidic glycoprotein in the bone matrix [15]. BMP2 plays a key role in osteogenesis. Its highest expression is in chondrocytes, osteoblasts and their precursors. It is responsible for the differentiation of mesenchymal stem cells into chondrocytes. It is also an important factor in the differentiation of osteoclasts (ODF), promoting osteoclastogenesis in late bone formation [16]. Furthermore, it is essential for the differentiation of odontoblasts and the formation of vessels in the pulp [17]. In addition, expression of the BMP-2 gene may be seen in numerous blood vessels and their cells [18].

\section{BMP-4}

This protein is encoded in humans by the BMP4 gene, on chromosome 14q22-q23 [19]. The main role of BMP-4 is to stimulate osteogenesis in the ectopic area, e.g. in subcutaneous tissue and muscle. It was also shown to be present in tumours (osteomyosarcoma) [20]. It is an important factor in mesodermal differentiation [21]. Together with activin it acts synergistically to promote early morphogenesis of mandibular and bark molars [22].

\section{BMP-6}

It is a protein encoded by the BMP6 gene [23]. Not only does it participate in the induction of osteogenic differentiation, but also in the body's innate immune response during the course of inflammatory processes and infections [24]. BMP6 is expressed mainly in cartilage tissue. It induces differentiation of mesenchymal cells into chondrocytes and stimulates synthesis of glycoproteins specific to articular cartilage [25]. It is a potent factor inducing bone growth [26] and an important regulator of the proliferation and differentiation of bone and cartilage cells [27, 28]. BMP-6 signals through activinlike kinase (ALK) and serine-threonine kinase receptors the phosphorylation of Smad proteins. BMP-6 may signal through type I Act-RIA, BMP-RIA and BMP-RIB receptors and type II BMP-RII, Act-RIIA and Act-RIIBi receptors and leads to the phosphorylation of the Smads receptor (Smad-1, Smad-5 and Smad-8). These receptors then form complexes with co-Smad (Smad4) and are transported to the cell nucleus, where they exert gene regulation. For BMP proteins, Smad activation is the main signalling pathway [29]. It is also known that BMP-6 is involved in embryonic skin development and influences cytoskeleton organization and collagen expression [30].

\section{BMP-7}

This protein participates in many physiological processes of the body, including embryogenesis, haematopoiesis, neurogenesis, and skeletal morphogenesis. Clinically, it is used to induce the differentiation of mesenchymal stem cells present in the area of a bone fracture into chondrocytes, osteoclasts and even form a new bone as a result of calcium deposition [31].

\section{THE APPLICATION OF BMP PROTEINS}

As early as 2009, Schuberth and his team showed that BMP proteins are very useful in patients undergoing foot and ankle surgery, who are at a high risk of bone healing complications. The results of such analyses showed that bone morphogenetic proteins in those patients proved to be useful [32].

The proteins BMP2 and BMP7 are particularly important in the treatment of acute and open shaft fractures of the tibia and facial surgery [33-35]. They have been approved by the 
US Food and Drug Administration (FDA). For facial surgery, the FDA-approved INFUSE ${ }^{\circledR}$ bone grafts, which consist of recombinant human BMP-2 placed on top of absorbable collagen sponges and are used to induce new bone tissue at the site of implantation [33]. BMP-2 is primarily used for bone regeneration. It has the ability to initiate a cascade of bone formation including migration of mesenchymal stem cells and their differentiation into osteoblasts [36]. Additionally, BMP-2 was found to induce ectopic bone formation, soft tissue hematomas, and bone resorption around implants [35, 37-39].

An alternative may be human bone morphogenetic protein-2 (hBMP-2) used for autologous bone grafting, which is used in a variety of orthopaedic procedures including spinal fusions, oral surgery, bone, cartilage, as well as tendon and ligament repair [40].

The BMP7 protein is used in rotor injuries, which usually lead to a prolonged pain and reduced mobility in the shoulder joint [41]. Gomes et al. [42] discovered that a postoperative injection of autologous bone marrow (BM) mononuclear cells can increase the functional status of a patient. This resulted in the opening of normal morphology of the tendon-bone junction. Finally, KGN successfully improved the quality of tendon healing following rotator cuff surgery [43]. BMP-7 was also shown to aid the complete integration of a tendon graft into newly formed trabecular bone during an anterior cruciate ligament reconstruction [44].

BMP-2 proteins are also used in traumatology, sports medicine, sports surgery, and spine surgery [45]. A disadvantage in using these proteins is their poor solubility at the physiological $\mathrm{pH}[33,46-48]$, rapid clearance and a relatively short biological half-life $[33,49]$.

BMP-7 proteins were used in the reconstruction of the alveolar cleft (Osigraft; Stryker Biotech, UK) [50]. 9 patients with unilateral jaws and 2 with bilateral cleft jaws were treated with RhBMP-7 [51]. The mean age of the patients was 10.4 years. Six months after the procedure, bone formation was observed on radiographs. The effects of BMP-7 on the course of orthodontic treatment and jaw growth were monitored for the subsequent 10 years.

A follow-up examination was performed every 3 days for the first 10 days, then every week for 3 months, and then after 6 months and after 1 year for 10 years. During each appointment, bone growth, tooth eruption and the interaction between the mandible and maxilla were monitored. Patients with unilateral cleft were radiographically assessed for normal bone formation, against the Kindelan score grades of 1 or 2 . In patients with bilateral cleft, the condition was graded 3 or 4 because of partial or complete bone abnormality. Orthodontic treatment was started in children who had received a transplant. The growth of the jaw with the use of BMP appeared to be similar to that with the use of autogenous bone. Longterm complications and abnormalities in bone growth were not detected [50].

A study was performed during which hydroxyapatite with recombinant rhBMP-2 factor was applied to the extraction sockets in the experimental group in order to preserve the alveolar process. However, in the control group, beef bone was inserted. The results were compared for both the histological and clinical bone formation. The height of the alveolar process in the two groups was similar, although the width was relatively smaller in the study group than in the control group. The percentage increase was on average from $25.37 \%$ to $17.23 \%$ in the experimental group and $6.13 \%$ to $4.32 \%$ in the control group. The use of rhBMP-2 / HA results in an increased ability to form new bone in the first 3 months compared to the use of bovine bone [52].

In addition, BMP7 is used in the treatment of cardiovascular diseases as an anti-fibrotic, anti-inflammatory and anti-apoptotic agent [53]. It is a protective factor in diabetic 
nephropathy [54,55] as well as in kidney cells [56]. BMP-7 was found to promote odontogenic differentiation of pulp-derived stem cells [57].

\section{BMP-4}

The BMP4 protein may be used in such fields of medicine as neurology and cardiology. Amyotrophic lateral sclerosis (ALS) is an adult-onset fatal neurodegenerative syndrome characterized by a systemic loss of motor neurons with marked astrocytosis and microgliosis in the spinal cord and the brain. Shijo et al. [58] showed that BMP4, with its downstream signalling, might be a new therapeutic target for therapies modifying the course of a disease in ALS [58]. It was also investigated whether spontaneous exercise increases the risk of progression of pathological cardiac hypertrophy with the involvement of BMP4 proteins. However, given the pro-inflammatory function of BMP4 induced by training, a reduction in bone BMP4 content may be beneficial for the failing heart, but more research is needed in order to better understand the relationship between bone metabolism and heart failure [59].

\section{BMP-6}

With the onset of menopause in women, the balance between bone regeneration and resorption processes is disturbed. They become brittle and prone to break easily. This is related to a decrease in osteoinduction resulting from a decrease in growth factors, such as bone morphogenetic proteins in the bone extracellular matrix [60]. Studies were performed involving systemic administration of recombinant BMP-6 protein to ovariectomised rats. These studies showed that the BMP-6 protein might be a bone anabolic agent with a systemic effect that may be used in patients with osteoporosis for bone regeneration [60].

Fractures among the elderly, especially those suffering from osteoporosis, are also a significant problem for medicine. BMP proteins have a therapeutic potential that enables a better fracture healing in such patients. Studies on mice were conducted in this regard. It was proven that the BMP-3 protein is the initiator of bone tissue repair with the highest intensity occurring 24 hours after the injury. In mice, the BMP-2 protein influenced the differentiation of mesenchymal stem cells (MSCs) into osteoblasts (together with BMP-6 and BMP-9 they act as the strongest signal for conversion) [61].

In one study BMP proteins were used to treat an open tibial fracture in 450 patients. During a one-year observation, it was noticed that higher doses of BMP2 effectively improved the bone healing process compared to patients treated in a standard way [62].

MSC and their transformation into osteoblasts are crucial in the implant treatment, the use of bone substitute materials and scaffolding for bone cells. What is characteristic and distinctive of the bone tissue that is formed through regeneration is that it is almost indistinguishable from the tissue that is undamaged. This differentiates it from soft tissues, where a scar is formed at the site of damage. BMP proteins, along with other factors, are involved in recruiting MSCs that multiply, differentiate and lead to bone formation around the injury by endothelial ossification approximately 7-10 days after the injury. This is followed by chondrogenesis under the signalling action of BMP, TGF-2 and -3, and in the next stage cartilage is transformed into the bone tissue [63].

\section{MATERIALS FOR BONE REGENERATION}

It is important that the area that undergoes bone regeneration is free from infection, both in bone tissue and in the surrounding tissues. It should also show an adequate level of blood supply. The patient's general diseases also reduce the regenerative capacity of the bones [64]. 
The materials used for bone regeneration induce the repair process by osteogenesis, osteoinduction and osteoconduction, and their selection should be adjusted in each case, e.g. to the size of the bone defect, biomechanical properties, shape and volume. 4 classes of materials used for supplementing bone defects are as follows:

a. autogenous: the material comes from the same person and is taken from a different area of the body; freshly harvested tissue contains living cells and osteoinductive factors, including BMP-2 and -7, FGF, IGF, and PDF. 41 Additional material shows no immunogenicity and no risk of viral disease transmission [65].

b. allogeneic preparations: the material comes from another person (the material comes from conspecific), collected from a living donor or corpse. However, this material displays immunogenic properties a risk of transmitting viral diseases and bacterial infections [66].

c. xenogeneic: it is derived from other species than humans (pigs, cattle), but carries a risk of transmitting zoonoses [67].

d. bone substitutes: they are capable of causing cell migration and proliferation, and their differentiation into cells is necessary for bone regeneration. Natural origin: collagen, elastin, alginate. Synthetic materials: hydroxyapatite, calcium phosphate cement [68].

Numerous studies have shown that porous silicon (pSi) may be used as a carrier for BMP [6971]. proteins due to its large surface area and porous volume, combined with its biocompatibility and ability to decompose into non-toxic products under physiological conditions [72, 73]. In addition, pSi has been found to have beneficial properties in the field of bone regeneration [74-79], including its ability to induce the growth of hydroxyapatite [80, 81]. pSi has been found to promote osteoblast adhesion and initiate the maturation process [82].

\section{PRACTICAL APPLICATION}

The current treatment strategies typically involve the use of autogenous bone grafts from such places as the fibula, iliac crest and ribs, the retromolar triangle area, the area between the mandibular foramen and mandible symphysis, tuberosity of maxilla, post-extraction site area, and outer oblique line. They are collected as non-vascularized or vascularized grafts. These transplants are characterized by numerous limitations, including degree of difficulty in performing the operation, risk of failure during surgery, bone resorption, complications at the site of anastomosis, severe infections and phantom pain [83, 84]. Therefore, a new, reliable bone regeneration strategy is needed [37].

As mentioned earlier, attention should be paid to proper blood supply to the area around the injury. Proper oxygen supply is necessary for osteoclasts and osteoblasts. Pressure on the transplanted material or its lack of stability disrupts its oxygen supply, thus disrupting regenerative processes. Therefore, it is recommended not to use a full or partial denture to eliminate pressure and quitting smoking, which reduces blood flow to the transplant site (vasoconstriction phenomenon) [68].

A) Autogenous grafts - taken from the ilium, tibia, ramus and the symphysis of the mandible. The disadvantages are two surgical fields (the site of the graft collection and the area for which the collected material was intended), hematomas, damage to nerve trunks, blood loss, pain during movements, and cosmetic defects. The material taken from the mandibular symphysis may cause sensory disturbances in the lower lip and chins.

Fretwurst et al. [85] conducted a study on 32 edentulous patients for whom bone augmentation was necessary before implantation. The material was collected from the iliac crest area and transplanted into the maxilla and mandible according to a standardized protocol. 150 implantations in total were carried out and then followed for an average of 69 months. The success rate was similar: $96 \%$ for the maxilla, and $92 \%$ for the mandible. 
Other studies [86] focused on fibula grafts for mandibular reconstruction. The fibula is often used for the reconstructive treatment of patients with head and neck tumours. Over 15 years of observation showed that in patients who had a vascular fibrous graft used for their implant therapy integration of the implants with the bone was stable. The tissue was also checked for the histological aspect of the graft and its properly vascular structure was found.

B) Allogeneic grafts - they contain BMP proteins, which are MSC cell inducers. The demineralization process, which the material is subjected to, exposes the BMP protein, and not only does it act on bone cells, but also stimulates angiogenesis. We distinguish two types of materials:

- mineralized materials which contain mineralized ingredients and collagen,

- demineralized materials which retain the collagen matrix.

It is assumed that the material with dimensions from 100 to $300 \mathrm{~mm}$ has the best osteoconductive potential. An advantage over the previously discussed material is that it is not necessary to create a second surgical field. Treatment outcomes are similar to those in autogenous transplants.

Studies by Xavier et al. [87] were conducted using allogeneic (material taken from a sheep) and an autogenous transplant for the treatment of lesions within the maxillary sinus. Then, computed tomography was performed after one week, six months and one year following the transplant. The results were similar.

Other studies [88] were carried out to restore the atrophied maxillary alveolar process using an allograft. Histological checks were performed after 4 months (progressive appearance of host cells in the transplant, weak, still developing new blood supply, sparse osteoclasts), 6 months (the graft is gradually replaced with new bone, although still with a low cell activity), and 9 months (areas of newly formed bone along with osteocyte gaps as a result of resorption).

C) Xenografts - low material cost, availability of a large amount of material is one of the advantages. They are collected mainly from cattle and horses and therefore require strict sterilization. For their application to be effective, BMP proteins or platelet-rich plasma must be used, and usually membranes are required to secure their stability. These materials are free of organic ingredients.

The stability of implants placed in grafts within the maxilla was tested [89]. In patients requiring mandibular regeneration and implantation, xenogenic and autogenous materials were used. Implants were introduced after the healing period. Tests were performed on each of them and no statistically significant differences in both cases were found.

D) Alloplastic materials - often used with allogeneic grafts. Studies comparing the use of autogenous grafts (taken from the mandible) and alloplastic material (calcium sulphate) were also conducted on 12 patients undergoing periodontal treatment. The transplanted sites healed after secondary exposure with good tissue coverage and soft tissue quality. No statistical difference in regeneration between the materials used was found [90].

\section{CONCLUSIONS}

BMP proteins have a wide range of applications, particularly in dentistry and sports medicine. They are important for bone regeneration. Their presence in materials used to stimulate reconstruction processes correlates, along with other factors, with the 
degree of their ability to repair bone defects. Hence, it is an opportunity for patients with developmental disorders, as well as patients after injuries, who do not accept their appearance. Thanks to bone regeneration resulting from the use of BMP, it is possible to improve their quality of life, both physically and psychologically.

The study demonstrates that autogenous material is the best for bone regeneration as a result of using resources of BMP proteins and bone-forming cells. Undeniably, the condition of the patient's body undergoing treatment with BMP is not without significance.

According to the authors of the article, all applications and treatment options with the use of BMPs are yet to be known. Perhaps further development of medicine will make their discovery possible.

\section{REFERENCES}

[1] Raggatt LJ, Partridge NC. Cellular and molecular mechanisms of bone remodeling. J Biol Chem. 2010;285(33):2510325108. https://doi.org/10.1074/jbc.R109.041087

[2] Huang W, Yang S, Shao J, Li YP. Signaling and transcriptional regulation in osteoblast commitment and differentiation. Front Biosci. 2007 May 1;12:3068-3092. https://doi.org/10.2741/2296

[3] Soltanoff CS, Yang S, Chen W, Li YP. Signaling networks that control the lineage commitment and differentiation of bone cells. Crit Rev Eukaryot Gene Expr. 2009;19(1):1-46. https://doi.org/10.1615/CritRevEukarGeneExpr.v19.i1.10

[4] Guo X, Wang XF. Signaling cross-talk between TGF-beta/BMP and other pathways. Cell Res. 2009 Jan;19(1):71-88. https://doi.org/10.1038/cr.2008.302

[5] Schliermann A, Nickel J. Unraveling the Cconnection between fibroblast growth factor and bone morphogenetic protein signaling. Int J Mol Sci. 2018;19(10):3220. Published 2018 Oct 18. https://doi.org/10.3390/ijms19103220

[6] Sasikumar KP, Elavarasu S, Gadagi JS. The application of bone morphogenetic proteins to periodontal and periimplant tissue regeneration: A literature review. J Pharm Bioallied Sci. 2012;4(Suppl 2):S427-S430. https://doi. org/10.4103/0975-7406.100320

[7] Thomadakis G, Ramoshebi LN, Crooks J, Rueger DC, Ripamonti U. Immunolocalization of bone morphogenetic Protein-2 and -3 and Osteogenic Protein-1 during murine tooth root morphogenesis and in other craniofacial structures. Eur J Oral Sci. 1999 Oct;107(5):368-77. https://doi.org/10.1046/j.0909-8836.1999.eos107508.x

[8] Dunn CA, Jin Q, Taba M Jr, Franceschi RT, Bruce Rutherford R, Giannobile WV. BMP gene delivery for alveolar bone engineering at dental implant defects. Mol Ther. 2005;11(2):294-299. doi:10.1016/j.ymthe.2004.10.005

[9] Yadin D, Knaus P, Mueller TD. Structural insights into BMP receptors: Specificity, activation and inhibition. Cytokine Growth Factor Rev. 2016 Feb;27:13-34. https://doi.org/10.1016/j.cytogfr.2015.11.005

[10] Katagiri T, Watabe T. Bone morphogenetic proteins. Cold Spring Harb Perspect Biol. 2016;8(6):a021899. https://doi. org/10.1101/cshperspect.a021899.

[11] Oida S, Iimura T, Maruoka Y, Takeda K, Sasaki S. Cloning and sequence of bone morphogenetic protein 4 (BMP4) from a human placental cDNA library. DNA Seq. 1995;5(5):273-5. https://doi.org/10.3109/10425179509030980

[12] Kimura M, Furukawa H, Shoji M, Shinozawa T. Increased mesodermal and mesendodermal populations by BMP4 treatment facilitates human iPSC line differentiation into a cardiac lineage. J Stem Cells Regen Med. 2019 Dec 24;15(2):45-51. https://doi.org/10.46582/jsrm.1502009

[13] Kwon HE, Jia S, Lan Y, Liu H, Jiang R. Activin and BMP4 signaling converge on Wnt activation during odontogenesis. J Dent Res. 2017;96(10):1145-1152. https://doi.org/10.1177/0022034517713710

[14] Park SY, Kim KH, Kim S, Lee YM, Seol YJ. BMP-2 Gene Delivery-Based Bone Regeneration in Dentistry. Pharmaceutics. 2019 Aug 5;11(8):393. https://doi.org/10.3390/pharmaceutics11080393

[15] Hudolin T, Kastelan Z, El-Saleh A, et al. Bone morphogenic proteins-2, -4, -6 and 7 in non-muscle invasive bladder cancer. Oncol Lett. 2020 Feb;19(2):1291-1297. https://doi.org/10.3892/ol.2019.11218

[16] Thompson DB, Ossowski V, Janssen RC, Knowler WC, Bogardus C. Linkage between stature and a region on chromosome 20 and analysis of a candidate gene, bone morphogenetic protein 2. Am J Med Genet. 1995 Dec 4;59(4):495-500. https://doi.org/10.1002/ajmg.1320590417

[17] Biver E, Hardouin P, Caverzasio J. The "bone morphogenic proteins" pathways in bone and joint diseases: translational perspectives from physiopathology to therapeutic targets. Cytokine Growth Factor Rev. 2013 Feb;24(1):69-81. https:// doi.org/10.1016/j.cytogfr.2012.06.003

[18] Wei B, Wang C, Yan C, et al. Osteoprotegerin/bone morphogenetic protein 2 combining with collagen sponges on tendon-bone healing in rabbits. J Bone Miner Metab. 2020 Jul;38(4):432-441.

[19] Liu Y, Buckley CT, Mulhall KJ, Kelly DJ. Combining BMP-6, TGF-B3 and hydrostatic pressure stimulation enhances the functional development of cartilage tissues engineered using human infrapatellar fat pad derived stem cells. Biomaterials Sci. 2013;1:745-752. https://doi.org/10.1039/c3bm60056d

[20] Miyazawa K, Shinozaki M, Hara T, Furuya T, Miyazono K. Two major SMAD pathways in TGF-beta superfamily signalling. Genes to Cells. 2002;7:1191-1204. https://doi.org/10.1046/j.1365-2443.2002.00599.x

[21] Arndt S, Karrer S, Hellerbrand C, Bosserhoff AK. Bone morphogenetic Protein-6 inhibits fibrogenesis in scleroderma offering treatment options for fibrotic skin disease. J Invest Dermatol. 2019 Sep;139(9):1914-1924.e6. https://doi. org/10.1016/j.jid.2019.02.020 
[22] van den Wijngaard A, Weghuis DO, Boersma CJ, van Zoelen EJ, Geurts van Kessel A, Olijve W. Fine mapping of the human bone morphogenetic protein-4 gene (BMP4) to chromosome 14q22-q23 by in situ hybridization. Genomics. 1995 Jun 10;27(3):559-60. https://doi.org/10.1006/geno.1995.1096

[23] Ripamonti U, Renton L. Bone morphogenetic proteins and the induction of periodontal tissue regeneration. Periodontol 2000. 2006;41:73-87. https://doi.org/10.1111/j.1600-0757.2006.00155.x

[24] Rutherford RB, Sampath TK, Rueger DC, Taylor TD. The use of bovine osteogenic protein to promote rapid osseointegration of endosseous dental implants. Int J Oral Maxillofac Implants. 1992;7:297-301.

[25] Yadin D, Knaus P, Mueller TD. Structural insights into BMP receptors: Specificity, activation and inhibition. Cytokine Growth Factor Rev. 2016 Feb;27:13-34. https://doi.org/10.1016/j.cytogfr.2015.11.005

[26] Hahn GV, Cohen RB, Wozney JM, et al. A bone morphogenetic protein subfamily: chromosomal localization of human genes for BMP5, BMP6, and BMP7. Genomics. 1992 Nov;14(3):759-762. https://doi.org/10.1016/S08887543(05)80181-8

[27] Sauermann U, Meyermann R, Schluesener HJ. Cloning of a novel TGF-beta related cytokine, the vgr, from rat brain: cloning of and comparison to homologous human cytokines. J Neurosci Res. 1993;33(1):142-7. https://doi.org/10.1002/ jnr.490330118

[28] Cook SD, Rueger DC Osteogenic protein-1: biology and applications. Clin Orthopaed Related Res. 1996;324:29-38. https://doi.org/10.1097/00003086-199603000-00005

[29] Choi S, Cho TJ, Kwon SK, Lee G, Cho J. Chondrogenesis of periodontal ligament stem cells by transforming growth factor- $\beta 3$ and bone morphogenetic protein-6 in a normal healthy impacted third molar. Int J Oral Sci. 2013;5(1):713. https://doi.org/10.1038/ijos.2013.19

[30] Kayabaşi GK, Tiğli Aydin RS, Gümüşderelioğlu M. In vitro chondrogenesis by BMP6 gene therapy. J Biomed Mater Res A. 2013;101:1353-61. https://doi.org/10.1002/jbm.a.34430

[31] Ma Y, Yao Y, Zhong N, Angwa LM, Pei J. The dose-time effects of fluoride on the expression and DNA methylation level of the promoter region of BMP-2 and BMP-7 in rats. Environ Toxicol Pharmacol. 2020 Apr;75:103331. https:// doi.org/10.1016/j.etap.2020.103331

[32] Schuberth JM, DiDomenico LA, Mendicino RW.The utility and effectiveness of bone morphogenetic protein in foot and ankle surgery. J FootAnkle Surg. 2009 May-Jun;48(3):309-14. https://doi.org/10.1053/j.jfas.2009.01.011

[33] El Bialy I, Jiskoot W, Reza Nejadnik M. Formulation, delivery and stability of bone morphogenetic proteins for effective bone regeneration. Pharm Res. 2017 Jun;34(6):1152-1170. https://doi.org/10.1007/s11095-017-2147-x

[34] Wozney JM. Bone morphogenetic proteins. Prog Growth Factor Res. 1989;1(4):267-80. https://doi.org/10.1016/09552235(89)90015-X

[35] Ben-David D, Srouji S, Shapira-Schweitzer K, et al. Low dose BMP-2 treatment for bone repair using a PEGylated fibrinogen hydrogel matrix. Biomaterials. 2013 Apr;34(12):2902-10. https://doi.org/10.1016/j.biomaterials.2013.01.035

[36] Yeh CH, Chang CK, Cheng MF, Lin HJ, Cheng JT. The antioxidativeeffect of bone morphogenetic protein-7 against high glucose-inducedoxidative stress in mesangial cells. Biochem Biophys Res Commun.2009;382(2):292-297. https:// doi.org/10.1016/j.bbrc.2009.03.011

[37] Rosenberg M, Shilo D, Galperin L, et al. BoneMorphogenicProtein2-LoadedPorousSiliconCarriers for OsteoinductiveImplants. Pharmaceutics. 2019 Nov 12;11(11):e602. https://doi.org/10.3390/pharmaceutics11110602

[38] Gottfried ON, Dailey AT. Mesenchymal stem cell and gene therapies for spinal fusion. Neurosurgery. 2008 Sep;63(3):38091; discussion 391-2. https://doi.org/10.1227/01.NEU.0000324990.04818.13

[39] Villavicencio AT, Burneikiene S, Nelson EL, Bulsara KR, Favors M, Thramann J. Safety of transforaminal lumbar interbody fusion and intervertebral recombinant human bone morphogenetic protein-2. J Neurosurg Spine. 2005 Dec;3(6):436-43. https://doi.org/10.3171/spi.2005.3.6.0436

[40] Suzuki MF, Oliveira JE, Damiani R, et al. Human bone morphogenetic protein-2 (hBMP-2) characterization by physicalchemical, immunological and biological assays. AMB Express. 2020 Feb 17;10(1):34. https://doi.org/10.1186/s13568020-0964-5

[41] Didesch JT, Tang P. Anatomy, etiology, and management of scapular winging. J Hand Surg Am. 2019 Apr;44(4):321330. https://doi.org/10.1016/j.jhsa.2018.08.008

[42] Ellera Gomes JL, da Silva RC, Silla LM, Abreu MR, Pellanda R. Conventional rotator cuff repair complemented by the aid of mononuclear autologous stem cells. Knee Surg Sports Traumatol Arthrosc. 2012 Feb;20(2):373-7. https:// doi.org/10.1007/s00167-011-1607-9

[43] Zhou Q, Zhang JH, Yuan S, et al. A new insight of kartogenin induced the mesenchymal stem cells (MSCs)selectively differentiate into chondrocytes by activating the bone morphogenetic protein 7 (BMP-7)/Smad5 pathway. Med Sci Monit. 2019 Jul 4;25:4960-4967. https://doi.org/10.12659/MSM.916696

[44] Mihelic R, Pecina M, Jelic M, et al. Bone morphogenetic protein-7 (osteogenic protein-1) promotes tendon graft integration in anterior cruciate ligament reconstruction in sheep. Am J Sports Med. 2004 Oct-Nov;32(7):1619-25. https://doi.org/10.1177/0363546504263703

[45] Bravo D, Jazrawi L, Cardone DA, et a. Orthobiologics A Comprehensive Review of the Current Evidence and Use in Orthopedic Subspecialties. Bull Hosp Jt Dis (2013). 2018 Dec;76(4):223-231.

[46] ImmunoTools GmbH. Recombinant Human Bone Morphogenetic Protein-2 (rh BMP-2). Available online: http://www. immunotools.de/html/cytokines.html (accessed on 27 October 2020).

[47] Friess W, Uludag H, Foskett S, Biron R. Bone regeneration with recombinant human bone morphogenetic protein-2 (rhBMP-2) using absorbable collagen sponges (ACS): influence of processing on ACS characteristics and formulation. Pharm Dev Technol. 1999 Aug;4(3):387-96. https://doi.org/10.1081/PDT-100101374

[48] Vallejo LF, Rinas U. Optimized procedure for renaturation of recombinant human bone morphogenetic protein-2 at high protein concentration. Biotechnol Bioeng. 2004 Mar 20;85(6):601-9. https://doi.org/10.1002/bit.10906

[49] Lo KW, Ulery BD, Ashe KM, Laurencin CT. Studies of bone morphogenetic protein-based surgical repair. Adv Drug Deliv Rev. 2012;64(12):1277-1291. https://doi.org/10.1016/j.addr.2012.03.014 
[50] Wang S, Hirschberg R. BMP7 antagonizes TGF-beta - dependentfibrogenesis in mesangial cells. Am J Physiol Renal Physiol. 2003;284:F1006-13. https://doi.org/10.1152/ajprenal.00382.2002

[51] Zhu L, Ma J, Mu R, Zhu R, Chen F, Wei X, Shi X, Zang S, Jin L. Bone morphogenetic protein 7 promotes odontogenic differentiation of dental pulp stem cells in vitro. Life Sci. 2018 Jun 1;202:175-181. https://doi.org/10.1016/j. lfs.2018.03.026

[52] Abu-Serriah MM, Odell E, Lock C, Gillar A, Ayoub AF, Fleming RH. Histological assessment of bioengineered new bone in repairing osteoperiosteal mandibular defects in sheep using recombinant human bone morphogenetic protein-7. Br J Oral Maxillofac Surg. 2004 Oct;42(5):410-8. https://doi.org/10.1016/j.bjoms.2004.05.005

[53] Ma Y, Yao Y, Zhong N, Angwa LM, Pei J. The dose-time effects of fluoride on the expression and DNA methylation level of the promoter region of BMP-2 and BMP-7 in rats. Environ Toxicol Pharmacol. 2020 Apr;75:103331. https:// doi.org/10.1016/j.etap.2020.103331

[54] Yang W, Harris MA, Cui Y, Mishina Y, Harris SE, Gluhak-Heinrich J. Bmp2 is required for odontoblast differentiation and pulp vasculogenesis. J Dent Res. 2012 Jan;91(1):58-64. https://doi.org/10.1177/0022034511424409

[55] Willette RN, Gu JL, Lysko PL, et al. BMP-2 gene expression and effects on human vascularsmooth muscle cells. J Vasc Res. 1999;36:20-125. https://doi.org/10.1159/000025634

[56] Aluganti Narasimhulu C, Singla DK. The role of bone morphogenetic protein 7 (bmp-7) in inflammation in heart diseases. Cells. 2020 Jan 23;9(2):E280. https://doi.org/10.3390/cells9020280

[57] Feng Y, Jin MY, Liu DW, Wei L. Bone morphogenetic protein (BMP 7) expression is regulated by the E3 ligase UBE4A in diabeticnephropathy. Arch Physiol Biochem. 2019;19:1-4. https://doi.org/10.1080/13813455.2018.1551905

[58] Shijo T, Warita H, Suzuki N, et al. Antagonizing bone morphogenetic protein 4 attenuates disease progression in a rat model of amyotrophic lateral sclerosis. Exp Neurol. 2018 Sep;307:164-179. https://doi.org/10.1016/j. expneurol.2018.06.009

[59] MajerczakJ, Filipowska J, Tylko G, et al. Impact of long-lastingspontaneousphysicalactivity on bonemorphogeneticprotein4 in the heart and tibia in murinemodel of heartfailure. Physiol Rep. 2020;(8):e14412. https://doi.org/10.14814/ phy2.14412

[60] Ayoub A, Roshan CP, Gillgrass T, Naudi K, Ray A. The clinical application of rhBMP-7 for the reconstruction of alveolar cleft. J Plast Reconstr Aesthet Surg. 2016 Jan;69(1):101-7. https://doi.org/10.1016/j.bjps.2015.09.004

[61] Ayoub A, Gillgrass T. The Clinical application of recombinant human bone morphogenetic protein 7 for reconstruction of alveolar cleft: 10 years' follow-up. J Oral Maxillofac Surg. 2019 Mar;77(3):571-581. https://doi.org/10.1016/j. joms.2018.08.031

[62] Shim JY, Lee Y, Lim JH, et al. Comparative Evaluation of Recombinant Human Bone Morphogenetic Protein-2/ Hydroxyapatite and Bovine Bone for New Bone Formation in Alveolar Ridge Preservation. Implant Dent. 2018 Dec;27(6):623-629. https://doi.org/10.1097/ID.0000000000000814

[63] Simic P, Culej JB, Orlic I, Grgurevic L, Draca N, Spaventi R, Vukicevic S. Systemically administered bone morphogenetic protein-6 restores bone in aged ovariectomized rats by increasing bone formation and suppressing bone resorption. J Biol Chem. 2006 Sep 1;281(35):25509-21. https://doi.org/10.1074/jbc.M513276200

[64] Dumic-Cule I, Peric M, Kucko L, Grgurevic L, Pecina M, Vukicevic S. Bone morphogenetic proteins in fracture repair Int Orthop. 2018 Nov;42(11):2619-2626. https://doi.org/10.1007/s00264-018-4153-y

[65] Cho TJ, Gerstenfeld LC, Einhorn TA. Differential temporal expression of members of the transforming growth factor $\beta$ superfamily during murine fracture healing. J Bone Mineral Res. 2002;17(3):513-20. https://doi.org/10.1359/ jbmr.2002.17.3.513

[66] Muschler G. Bone graft materials; an overview of the basic science. Clin Orthop. 2000;371:10-4. https://doi. org/10.1097/00003086-200002000-00003

[67] Janicki P, Schmidmaier G. What should be the characteristics of the ideal bone graft substitute Combining scaffolds with growth factors and/or stem cells. Injury. 2011;42:77-81. https://doi.org/10.1016/j.injury.2011.06.014

[68] Ehrler DM, Vaccaro AR. The use of allograft bone in lumbar spine surgery. Clinical orthopaedics and related research. 2000;371:38-45. https://doi.org/10.1097/00003086-200002000-00005

[69] Gu L, Park JH, Duong KH, Ruoslahti E, Sailor MJ. Magnetic luminescent porous silicon microparticles for localized delivery of molecular drug payloads. Small. 2010 Nov 22;6(22):2546-52. https://doi.org/10.1002/smll.201000841

[70] Santos HA, Mäkilä E, Airaksinen AJ, Bimbo LM, Hirvonen J. Porous silicon nanoparticles for nanomedicine: preparation and biomedical applications. Nanomedicine (Lond). 2014 Apr;9(4):535-54. https://doi.org/10.2217/nnm.13.223

[71] Tasciotti E, Liu X, Bhavane R, et al. Mesoporous silicon particles as a multistage delivery system for imaging and therapeutic applications. Nat Nanotechnol. 2008;3:151. https://doi.org/10.1038/nnano.2008.34

[72] Anglin EJ, Cheng L, Freeman WR, Sailor MJ. Porous silicon in drug delivery devices and materials. Adv Drug Deliv Rev. 2008;60(11):1266-1277. https://doi.org/10.1016/j.addr.2008.03.017

[73] Salonen J, Kaukonen AM, Hirvonen J, Lehto VP. Mesoporous silicon in drug delivery applications. J Pharm Sci. 2008 Feb;97(2):632-53. https://doi.org/10.1002/jps.20999

[74] Fan D, Akkaraju GR, Couch EF, Canham LT, Coffer JL. The role of nanostructured mesoporous silicon in discriminating in vitro calcification for electrospun composite tissue engineering scaffolds. Nanoscale. 2011 Feb;3(2):354-61. https:// doi.org/10.1039/C0NR00550A

[75] Gutiérrez-Prieto SJ, Perdomo-Lara SJ, Diaz-Peraza JM, Sequeda-Castañeda LG. Analysis of In Vitro Osteoblast Culture on Scaffolds for Future Bone Regeneration Purposes in Dentistry. Adv Pharmacol Sci. 2019;2019:5420752. https:// doi.org/10.1155/2019/5420752

[76] Hing KA, Revell PA, Smith N, Buckland T. Effect of silicon level on rate, quality and progression of bone healing within silicate-substituted porous hydroxyapatite scaffolds. Biomaterials. 2006 Oct;27(29):5014-26. https://doi. org/10.1016/j.biomaterials.2006.05.039

[77] Murphy MB, Blashki D, Buchanan RM, et al. Multi-composite bioactive osteogenic sponges featuring mesenchymal stem cells, platelet-rich plasma, nanoporous silicon enclosures, and Peptide amphiphiles for rapid bone regeneration. J Funct Biomater. 2011 Jun 21;2(2):39-66. https://doi.org/10.3390/jfb2020039 
[78] Pastor EL, Reguera-Nuñez E, Matveeva E, Garcia-Fuentes M. Pore size is a critical parameter for obtaining sustained protein release from electrochemically synthesized mesoporous silicon microparticles. PeerJ. 2015 Oct 6;3:e1277. https://doi.org/10.7717/peerj.1277

[79] Whitehead MA, Fan D, Mukherjee P, Akkaraju GR, Canham LT, Coffer JL. High-porosity poly(epsilon-caprolactone)/ mesoporous silicon scaffolds: calcium phosphate deposition and biological response to bone precursor cells. Tissue Eng Part A. 2008 Jan;14(1):195-206. https://doi.org/10.1089/ten.a.2006.0370

[80] Canham LT. Bioactive silicon structure fabrication through nanoetching techniques. Adv Mater. 1995;7:1033-1037. https://doi.org/10.1002/adma.19950071215

[81] Gryshkov O, Klyui NI, Temchenko VP, et al. Porous biomorphic silicon carbide ceramics coated with hydroxyapatite as prospective materials for bone implants. Mater Sci Eng C Mater Biol Appl. 2016 Nov 1;68:143-152. https://doi. org/10.1016/j.msec.2016.05.113

[82] Angelescu A, Kleps I, Mihaela M, et al. Porous silicon matrix for applications in biology. Rev Adv Mater Sci. 2003;5:440449.

[83] Boone DW. Complications of iliac crest graft and bone grafting alternatives in foot and ankle surgery. Foot Ankle Clin. 2003 Mar;8(1):1-14. https://doi.org/10.1016/S1083-7515(02)00128-6

[84] Velchuru VR, Satish SG, Petri GJ, Sturzaker HG. Hernia through an iliac crest bone graft site: Report of a case and review of the literature. Bull Hosp Jt Dis. 2006;63(3-4):166-8.

[85] Fretwurst T, Nack C, Al-Ghrairi M, et al. Long-term retrospective evaluation of the peri-implant bone level in onlay grafted patients with iliac bone from the anterior superior iliac crest. J Craniomaxillofac Surg. 2015 Jul;43(6):95660. https://doi.org/10.1016/j.jcms.2015.03.037

[86] Duttenhoefer F, Nack C, Doll C, et al. Long-term peri-implant bone level changes of non-vascularized fibula bone grafted edentulous patients. J Craniomaxillofac Surg. 2015 Jun;43(5):611-5. https://doi.org/10.1016/j.jcms.2015.02.020

[87] Xavier SP, Silva ER, Kahn A, Chaushu L, Chaushu G. Maxillary sinus grafting with autograft versus fresh-frozen allograft: a split-mouth evaluation of bone volume dynamics. Int J Oral Maxillofac Implants. 2015 Sep-Oct;30(5):1137-42. https:// doi.org/10.11607/jomi.3924

[88] Acocella A, Bertolai R, Ellis E 3rd, Nissan J, Sacco R. Maxillary alveolar ridge reconstruction with monocortical freshfrozen bone blocks: a clinical, histological and histomorphometric study. J Craniomaxillofac Surg. 2012 Sep;40(6):52533. https://doi.org/10.1016/j.jcms.2011.09.004

[89] Lima RG, Lima TG, Francischone CE, et al. Bone volume dynamics and implant placement torque in horizontal bone defects reconstructed with autologous or xenogeneic block bone: A randomized, controlled, split-mouth, prospective clinical trial. Int J Oral Maxillofac Implants. 2018 Jul/Aug;33(4):888-894. https://doi.org/10.11607/jomi.6288

[90] Orsini M, Orsini G, Benlloch D, et al. Comparison of calcium sulfate and autogenous bone graft to bioabsorbable membranes plus autogenous bone graft in the treatment of intrabony periodontal defects: A split-mouth study. J Periodontol. 2001 Mar;72(3):296-302. https://doi.org/10.1902/jop.2001.72.3.296 